\title{
The long-term effects of out-of-home placement in late adolescence: A propensity score matching analysis among Swiss youths
}

\author{
Margit Averdijk University of Zurich, Switzerland \\ margit.averdijk@jacobscenter.uzh.ch \\ Denis Ribeaud University of Zurich, Switzerland \\ Manuel Eisner University of Cambridge, UK
}

(Received February 2017

Revised November 2017)

http://dx.doi.org/10.14301/llcs.v9i1.450

\begin{abstract}
The aim of this study was to examine the outcomes of out-of-home placement in adolescence. We used data from a longitudinal study of Swiss youths and measured all outcomes, including externalising problem behaviour, anxiety and depression, education, and self-efficacy at age 17 . Propensity score matching was used to reduce selection effects and multiple imputation to treat the missing values. The findings revealed that youths who were placed in out-of-home care come from disproportionately problematic backgrounds, which complicated their proper matching to youths who were not placed in out-of-home care. Outcome analyses including multiple robustness checks suggest that negative outcomes among youths who were placed in out-of-home care are not so much due to the placement itself, but largely to pre-existing difficulties present already before the placement.
\end{abstract}

\section{Keywords}

Foster care; problem behaviour; delinquency; longitudinal; propensity score matching

\section{Introduction}

Children and youths who spend part of their childhood in out-of-home care have been described as a vulnerable group. Not only is out-of-home placement typically a marker of prior adversities such as abuse, neglect, parental mental illness, poverty, and behavioural and socio-emotional problems (Pecora et al., 2006; Pilowsky \& Wu, 2006; Rosenfeld et al., 1997: Vanderfaellie, Pijnenburg, Damen, \& van Holen, 2015), youths who have been placed out of the home also report significant problems later in life, including low levels of education and employment and high-risk behaviours such as unsafe sex, drug abuse, and delinquency (Berzin, 2008; Courtney \& Dworsky, 2006; Kortenkamp \& Ehrle, 2002; Taussig, 2002).
It is largely unknown, though, which factors are responsible for these maladaptive outcomes. On the one hand, the pre-existing vulnerabilities of children and youths before entering out-of-home care may predispose them to adverse outcomes. Indeed, prior research has attested to the vulnerable histories of these children and youths, including parenting problems and family challenges (e.g. Holland \& Gorey, 2004). On the other hand, it is possible that the separation from a familiar environment or characteristics of the out-of-home care situation may aggravate symptoms. For example, the separation from the home environment may disrupt existing bonds (beyond the child-parent bond), thereby leading to unstable attachments and disrupted feelings of 
belongingness (Baumeister \& Leary, 1995). Even dissolving bad or destructive relationships has been argued to potentially lead to distress. It is known that breaking off attachments can lead to a lack of belongingness, in turn leading to a low perceived meaningfulness of life and a variety of maladaptive outcomes, including both internalising and externalising behaviour (Baumeister \& Leary, 1995; Lambert et al., 2013; Stillman \& Baumeister, 2009).

A third possibility, which is more in line with the goals of out-of-home care within the child protection system (Blülle, 2013), is that out-ofhome care alleviates negative outcomes by providing youths with a break from a potentially abusive or otherwise detrimental situation. To this extent, the chronic distress and increasing demand on coping skills in the home environment can deplete psychological and physical resources, thereby increasing allostatic load and contributing to a variety of maladaptive conditions (Danese \& McEwen, 2012; Ganzel, Morris, \& Wethington, 2010; McEwen, 1998). If removal from the stressful environment is perceived as a positive life change, then it might not only lead to stress reduction, but also open up new opportunities for positive development. Indeed, research on therapeutic outof-home care programs has shown that intensive structured support programs for foster parents and youths are capable of decreasing problem behaviour (Chamberlain et al., 2008; Macdonald \& Turner, 2008; Westermark, Hansson, \& Olsson, 2011).

The main reason that knowledge on the outcomes of foster care is still limited despite the large number of studies that has been conducted is that the vast majority of prior studies suffers from methodological challenges. In particular, most research has been conducted among samples of children and youths who have been placed in outof-home care only, therefore lacking a comparison group. To investigate the effects of out-of-home placement, it would be ideal from a research perspective to compare a sample of youths that has been randomly selected to enter the out-of-home care system to one that did not (Pilowski \& Wu, 2006). Due to the obvious ethical difficulties involving such a research design, this is not possible. The next best option from a methodological perspective is to use longitudinal data collected among a population sample, study changes in outcomes before and after out-of-home placement among those placed in out-of-home care, and compare these to changes among those who were not placed in out-of-home care. To our knowledge, no such study has been conducted to date.

Studies that have been conducted have either compared children who were placed in out-of-home care to children who were not, or have studied the behaviour of children who were placed in out-ofhome care at different points during and after outof-home care. The first type of studies has shown that children and youths who were placed in out-ofhome care have a higher prevalence of problem behaviour later on, including conduct problems, delinquency, reincarceration, and risky sexual behaviour compared to community norms or comparison groups not placed in out-of-home care (Clausen, Landsverk, Ganger, Chadwick, \& Litrownik, 1998; Courtney et al., 2016; Jung \& LaLonde, 2016; Ryan \& Testa, 2005; Schmid, Kölch, Fegert, \& Schmeck, 2013). They also have higher rates of mental disorders, suicide attempts, depression, substance use disorders, inhalant abuse, homeless shelter use, and lower physical health (Courtney et al., 2016; dosReis, Zito, Safer, \& Soeken, 2001; Herman, Susser, \& Struening, 1994; Park, Metraux, \& Culhane, 2005; Pilowski et al., 2006; Wu, Pilowsky, \& Schlenger, 2004). In addition, youths placed in out-of-home care find themselves in less favorable socio-economic circumstances, having lower eduational attainment, employment rates, and earnings (Cook, 1994; Courtney \& Dworsky, 2006; Dworsky, 2005; Pecora et al., 2006). For example, compared to young adults matched on educational attainment, youths who were in out-ofhome care earned about half and the employment rate was about 20 points lower (Okpych \& Courtney, 2014).

The second type of studies (studies that examine changes in behaviour at different points during and after out-of-home placement) is much smaller in number and findings have been conflicting. Whereas an older Canadian study showed that emotional and behaviour problems generally remained stable or increased during placement (Palmer, 1976), two more recent studies from Australia and Switzerland found that they improved over time (Barber and Delfabbro, 2005; Schmid et al., 2013). These differences may in part be due to differences between the child care welfare systems (and changes therein over time) in the countries 
where the studies were conducted, although there has also been evidence that the initial severity of children's problem behaviour and the informant who reports the information in the survey play a role (Newton, Litrownik, \& Landsverk, 2000; Van Oijen, 2010).

Although these studies have been important in increasing our knowledge on the outcomes of children and youths placed in out-of-home care, it is still too early to draw conclusions on the effects of out-of-home care as currently delivered. Many studies did not control for relevant covariates or only a limited amount. Those studies that used matched samples to control bias included only few covariates for matching (e.g. Blome, 1997; McCord, J., McCord, W., \& Thurber, 1960; Okpych \& Courtney, 2014). As a consequence, it is largely unclear to what extent the documented unfavourable outcomes among children and youths who were placed in out-of-home care are due to pre-existing childhood adversities, maturation, or the out-of-home placement per se. Furthermore, the vast majority of studies have been conducted in the United States.

Our aim in this study was to help fill some of these research gaps by using a large longitudinal population sample of urban youths in combination with a propensity score matching approach. Using this approach, we matched youths who were placed in out-of-home care with youths who were not on a large number of covariates collected among multiple informants to reduce selection bias. Given the broad range of outcomes that have been linked to out-of-home care, we included outcomes across multiple life domains, including anti-social behaviour, mental health, education, and selfefficacy at age 17.

Our study was conducted in Switzerland. Although no official statistics exist (Zatti, 2005), it is estimated that between 22,000 and 30,000 children and youths ( 1.5 to $2 \%$ of minors (Federal Statistical Office, 2010-2015)) do not live with their parents in Switzerland (Keller, 2012). These children and youths temporarily or permanently grow up in foster families or stationary institutions. They are often placed in these arrangements as part of child protection interventions or referrals by the youth justice system. Out-of-home placements in Switzerland are usually a last resort after interventions within the family have failed or when such placements are deemed necessary for the child's welfare. The sector is weakly regulated and the quality of the help process relies to a significant extent on the qualifications of the case workers (Huwiler, Raulf, Tanner, Wicky, \& Arnold, 2008). However, steps have been taken to improve quality control and professionalism. A quality standard was developed by five organisations in 2004 (see Netzwerk IPK, 2013), and a new and revised regulation (Pflegekinderverordnung, PAVO) stepped into force in 2013. In 2010, the criteria for a quality label for foster family placement organisations were developed (Integras, 2013), for which seven organisations have been certified (Integras, status: 24 May 2016). Another initiative was launched as part of a European strategy for the introduction of quality standards (Quality4Children Switzerland). Finally, foster family mediation organisations, especially the larger ones, offer training and supervision for foster parents, and promote the training of professionals and local authorities' members as well as scientific research into the development and quality of foster family arrangements (Gassmann, 2008, 2013).

Our study focused on effects of out-of-home placement on problem behaviour in late adolescence. In late adolescence, out-of-home placement and leaving care may result in limited possibilities for making a successful transition into the relative autonomy of emerging adulthood due to limited social and economic support structures to fall back on (Biehal \& Wade, 1996; Lee, 2012; Ossipow, Aeby, \& Berthod, 2013). Youths placed in out-of-home care, especially stationary institutions, have reported that although there is a strong focus on promoting education and integration into work life, there is a lack of possibilities to explore the life skills, independence, and social relations that are needed to successfully manage autonomy after leaving out-of-home care and entering emerging adulthood (Schaffner \& Rein, 2013). Also, the instability and insecurity of the out-of-home care situation and the lack of warm and/or enduring family relationships have been reported to form major obstacles in building meaningful relationships with others (Love, McIntosh, Rost, \& Tertzakian, 2005; Samuels, 2008). This may be especially problematic for foster care youths, who have to manage the transition from dependent adolescence to independent adulthood while being less likely to be able to rely on the support of their (extended) family, which is recognised to be an important 
contributor to a successful transition to adulthood (Courtney \& Heuring; 2005; Mortimer \& Larson, 2002). In addition, emerging adulthood is not only a life period increasingly manifesting itself as characterised by frequent change, identity formation, and exploration of possible life directions, but also by decreased monitoring by caregivers and a heterogeneity of possible life pathways with little structure, which lends itself to high rates of risk behaviour (Arnett, 2000). With decreased support structures to fall back on, foster care youths may be especially vulnerable in this period in life (Osgood, Foster, Flanagan, \& Ruth, 2005).

\section{Data}

\section{Sample}

Data were drawn from the ongoing combined longitudinal and intervention study, the Zurich Project on the Social Development from Childhood into Adulthood (z-proso;) (Eisner, Malti, \& Ribeaud, 2011). After stratification by enrolment size and socioeconomic background of the school district, a sample of 56 schools was drawn in the city of Zurich, Switzerland. The final target sample was all 1,675 first graders (age 7). The implemented interventions did not affect anti-social outcomes in any substantive way (Averdijk, Zirk-Sadowski, Ribeaud, \& Eisner, 2016; Malti, Ribeaud, \& Eisner, 2011). The sample was $52 \%$ male. In $46 \%$ of all cases, both parents were born outside of Switzerland. Table 1 provides an overview of the participation rates and sample age for each timepoint.

\section{Procedure}

In line with local data protection regulations, active parental consent was obtained before the first and again before the fourth data collection. From age 13 onwards, youths provided active and the parents passive consent. From the first to the third data collection, computer-assisted interviews lasting 45 minutes were conducted with the children at school. From age 11 onwards, the youths completed a paper-and-pencil questionnaire of approximately 90 minutes' duration. At age 11, the youth assessments took place during regular school hours; from age 13 forward they took place outside regular school hours. The youths received a financial incentive worth the equivalent of 30, 50, and 60 USD at ages 13,15, and 17. Computerassisted parent interviews were conducted at the respondent's home and ceased after four data collections; the incentive for the parents was a voucher worth the equivalent of 50 USD. Teachers completed a paper-and-pencil questionnaire at all data collections.

\section{Data analysis}

We used propensity score matching (PSM) to remove pre-existing differences between youths who were placed in out-of-home care and those who were not as much as possible. PSM has become a popular method in the social sciences (e.g. Apel \& Sweeten, 2010) and has been successfully applied to the z-proso data (Eisner, Nagin, Ribeaud, \& Malti, 2012; Obsuth et al., 2016). PSM has been recommended for data analyses with rare exposures, such as in our case (Ross et al., 2015), and was used to match each youth who was placed in out-of-home care to one or more other youths who were not placed in out-of-home care, but 'looked like' the first youth on other relevant variables. The goal was to ensure that youths in out-of-home care had insignificant mean differences across key background covariates compared to youths not in out-of-home care. The advantage of PSM over other matching techniques is its ability to match youths on a very large set of covariates.

As a first step, we estimated the propensity score, which is the conditional probability of being assigned to a certain treatment given the observed covariates (Rosenbaum \& Rubin, 1984). To this end, the treatment (i.e. placement in out-of-home care) was regressed on all covariates in a logit regression. The second step was to assess whether the youths in out-of-home care were indeed similar to their matched partners on all relevant covariates, a condition known as 'common support'. In the third step, the effects of out-of-home care on the age 17 outcomes were estimated.

Youths were matched using optimal matching, which has been shown to have advantages over greedy matching, most importantly minimising the total average distance within all matched pairs (Guo \& Fraser, 2010). To find the optimal matching structure and assess sensitivity of the estimates to the matching method (Apel \& Sweeten, 2010), we carried out 1-to-1 pair matching (where each youth placed in out-of-home care was matched to the youth with the closest propensity score who was not placed in out-of-home care), 2-to-1 pair 


\section{Table 1. Study participation and sample age for each time-point.}

\begin{tabular}{|c|c|c|c|c|}
\hline \multirow[t]{2}{*}{ Time-point } & \multicolumn{3}{|c|}{ Number of participants (\%) of original target sample } & \multirow{2}{*}{$\begin{array}{l}\text { Child age at child interview } \\
\qquad(M, S D)\end{array}$} \\
\hline & Child & Parent & Teacher & \\
\hline 1 & $1,361(81.3 \%)$ & $1,240(74.0 \%)$ & $1,350(80.6 \%)$ & $7.45(.39)$ \\
\hline 2 & $1,335(79.7 \%)$ & $1,192(71.2 \%)$ & $1,325(79.1 \%)$ & $8.11(.38)$ \\
\hline 3 & $1,322(78.9 \%)$ & $1,181(70.5 \%)$ & $1,294(77.3 \%)$ & $9.10(.38)$ \\
\hline 4 & $1,148(68.5 \%)$ & $1,075(64.2 \%)$ & $1,064(63.5 \%)$ & $11.33(.37)$ \\
\hline 5 & $1,366(81.6 \%)$ & n.a. & $1,269(75.8 \%)$ & $13.67(.37)$ \\
\hline 6 & $1,447(86.4 \%)$ & n.a. & $1,293(77.2 \%)$ & $15.44(.36)$ \\
\hline 7 & $1,306(78.0 \%)$ & n.a. & 904 (54.0\%) & $17.45(.37)$ \\
\hline
\end{tabular}


matching (where each youth placed in out-of-home care was matched to the two closest youths who were not placed in out-of-home care), full matching (where all cases were grouped into sets that contained at least 1 youth placed in out-of-home care and 1 youth not placed in out-of-home care, and where all youths were placed into a set, so that each set typically contained either 1 youth in outof-home care and multiple youths not in out-ofhome care, or 1 youth not in out-of-home care and multiple youths in out-of-home care), and constrained full matching (which is the same as full matching except that it limits the ratio of youths placed in out-of-home care to youths not placed in out-of-home care in each matched set). Results were similar. As full and constrained full matching are considered more flexible and efficient compared to nearest neighbour matching because more cases are retained in the analysis, leading to lower variance and potentially lower bias (Stuart \& Green, 2008), we present the results of the full and constrained full matching below. For constrained full matching, we erred on the side of caution by limiting the ratio of youths placed in out-of-home care to youths not placed in out-of-home care to range from 2:5 to 1:10 (Stuart \& Green, 2008), which implied that not all youths who were not placed in out-of-home were matched. We used the matchit package (Ho, Imai, King, \& Stuart, 2011) with the add-on package optmatch (Hansen, 2004) in $\mathrm{R}$ to carry out the matching.

Next, the outcomes of out-of-home placement were estimated using weighted regression models in Stata 12 (StataCorp, 2011). Youths who were placed in out-of-home care received a weight of 1 . The weights for the youths who were not placed in out-of-home care were constructed as being proportional to the number of youths placed in outof-home care in a particular set divided by the number of youths not placed in out-of-home care in that set. The weights of the youths who were not placed in out-of-home care were then scaled to equal the number of matched youths not placed in out-of-home care (Ho et al., 2011; Stuart \& Green, 2008).

For the current analysis, we included only those youths who participated in at least one of the data collections in which the key study variables were measured (i.e. at age 13,15 , or 17$)(N=1,483)$. We used multiple imputation using fully conditional specification in SPSS to treat the missing data; the number of imputations was 10 . We performed the matching as well as all tests and regressions for each imputation separately and then calculated the overall estimates according to the rules described by Allison (2001).

\section{Predictor}

Out-of-home placement. Out-of-home placement was measured at ages 13,15 , and 17 using a Life Event Calendar (LEC). LECs involve placing events and circumstances on calendars in order to capitalise on the sequential and hierarchical storage of memory (Roberts \& Horney, 2010). For each of a variety of listed events, among which was 'You moved in with a foster family or moved to a foster home' (where 'foster home' translates to a group home), the youths were asked to report whether or not they had experienced it in the past two years. Those youths who reported that they had been placed in out-of-home care were asked in which of the previous semesters this had happened. Because our measure of out-of-home care at age 17 was measured at the same timepoint as the outcomes, we included only out-ofhome placements in the first two semesters (i.e. age 16) at this time-point to guarantee causal ordering in relation to the outcomes.

\section{Outcomes at age 17}

A range of outcomes at age 17 was assessed, reflecting outcomes examined in the existing literature.

Delinquency. The youths reported on the pastyear prevalence of 14 different types of delinquency. Items included stealing at home, stealing at school, shoplifting something worth more than 50 dollars, shoplifting something worth less than 50 dollars, vehicle theft, driving without a license, burglary and stealing from a car, drug dealing, graffitiing, vandalism, carrying a weapon, threatening and extortion, robbery, and assault. The scale was adapted from Wetzels, Enzmann, Mecklenburg, and Pfeiffer (2001). All items were coded as a dichotomy of 0 ('did not commit the offence') and 1 ('did commit the offence'). Next, a variety scale was computed (Bendixen, Endresen, \& Olweus, 2003). Variety scales have been termed 'the preferred criminal offending scale' because they display high reliability and validity, are less skewed than frequency measures, and are not compromised by high-frequency crime-types of low seriousness (Sweeten, 2012). 
Aggression. Aggression was self-reported by the youths using the Social Behavior Questionnaire (SBQ; Tremblay et al., 1991). Tremblay et al. (1991) reported internal consistency, test-retest reliability, stability over time, and concurrent and predictive validity. Responses across 9 items (e.g. 'You physically attacked other people') were recorded on a 5-point Likert scale ranging from 1 'never' to 5 'very often'. We averaged these items $(\alpha=.80)$.

Self-reported police contacts related to an offense. For each type of youth-reported delinquency described above, a follow-up item assessed the prevalence of a police contact for that delinquent act. We constructed an overall prevalence score across all items. ${ }^{1}$

Substance use. Eight self-report items measured the past-year consumption of tobacco, alcohol, strong liquor, marijuana, ecstasy, amphetamines, cocain, and psychedelics in the past 12 months. Answer categories on a 6-point scale ranged from 1 ('never') to 6 ('daily'). After recoding the category 1 to 0 and the categories 2 through 5 to 1 , we computed the final score as a variety scale.

Optimism. Four items measured the youths' feelings of optimism (e.g. 'I'm happy'). The scale was self-developed by the z-proso team. Responses on the items ranged from 1 'fully untrue' to 4 'fully true' $(\alpha=.78)$.

Anxiety and depression. The youths reported on their internalising problems in the past month using the SBQ. Nine items were included (e.g. 'I was sad without knowing why'). Responses varied from 1 'never' to 5 'very often'. We averaged the items ( $\alpha$ $=.82$ ).

Suicidal ideation. One item asked the youths about suicidal ideation in the past month ('I thought about killing myself').

Low education. A variable was constructed that reflected the school level that the youths attended at age 17. Categories ranged from high (1 'Grammar school or equivalent') to low education (5 'Profession choice year, special needs class, or not in education').

School commitment. Four items measured the youth's school commitment (e.g. 'I do all my homework'). Answer categories ranged from 1 'fully untrue' to 4 'fully true' $(\alpha=.64)$.

Generalised trust. Trust was measured through three items (e.g. 'Most people can be trusted'). Answer categories ranged from 'fully untrue' to 4 'fully true' $(\alpha=.83)$.
Self-efficacy. We included five items measuring self-efficacy on a 4-point scale from 1 'fully untrue' to 4 'fully true' (e.g. 'If there are difficulties, I find ways or means to overcome them', $\alpha=.67$ ).

\section{Covariates for the matching procedure}

The success of matching depends on the set of included covariates (Smith \& Todd, 2005). Our data were particularly suitable for matching due to the richness in variables related to both treatment and outcomes. We first selected 161 covariates for potential inclusion based on their developmental relevance and prior analyses (Eisner et al., 2012; Obsuth et al., 2016). However, computational difficulties prohibited us from using the full set of covariates. We therefore subjected all 161 covariates to $t$-tests to examine differences between youths who were placed in out-of-home care and those who were not. If the same covariates were measured at multiple time-points, more recent measures were given priority based on the logic that more proximate variables typically have higher influence. we also included sex (" 0 " for females, "1" for males)

due to its importance in predicting child development. This resulted in a final selection of 83 covariates (table 2). The covariates were collected among multiple informants (parents, teachers, children, and peers) and in the first four data collections to ensure that they were not influenced by the predictor variable (out-of-home placement).

\section{Results \\ Descriptive statistics}

Between age 11 and 17, 47 youths (3.9\%) were placed in out-of-home care (table 3 ). Initial $t$-tests between the youths who were placed in out-ofhome care and those who were not showed that youths who were placed in out-of-home care came from significantly more problematic socio-economic and family backgrounds and displayed more problem behaviour. An overview of the differences between all covariates between the two groups is shown in appendix 1.

\section{Results of the matching procedure}

Success of the matching procedure was examined in three ways. First, we inspected histograms and jitter plots of the propensity scores. These demonstrated evidence of lacking common support (see figures 1 and 2 for examples). Although the groups demonstrated considerably 
Table 2. Covariates included for the Matching Procedure.

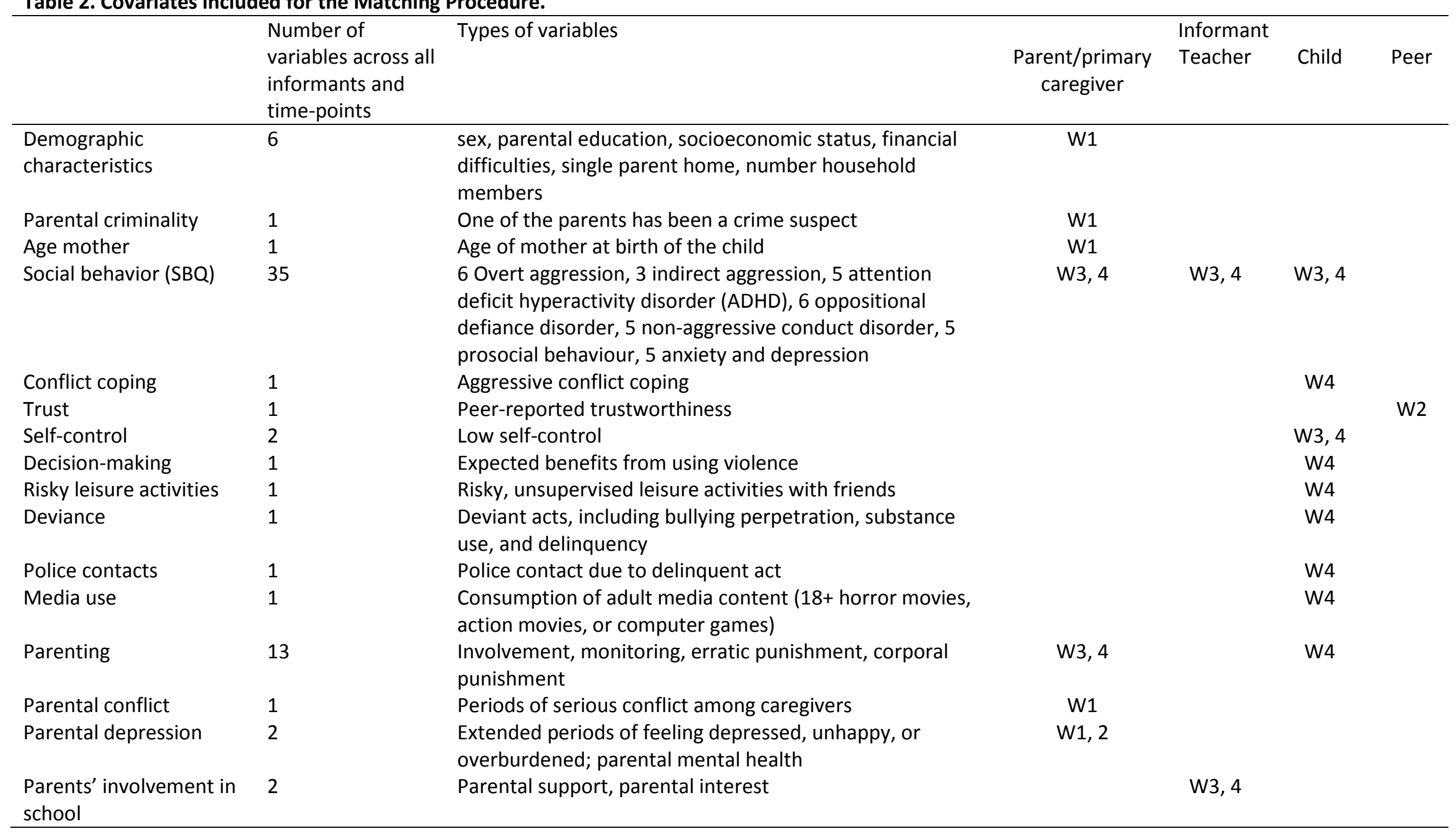


Table 2. Continued. Covariates included for the Matching Procedure .

$\begin{array}{lcc}\text { Number of } & \text { Types of variables } & \text { Informant } \\ \text { variables across all } & \text { Parent/primary } & \text { Teacher } \\ \text { informants and } & \text { caregiver } & \text { Peer } \\ \text { time-points } & & \end{array}$

time-points

\begin{tabular}{|c|c|c|c|c|c|c|}
\hline Family climate & 1 & Interactions and climate within family & W3 & & & \\
\hline $\begin{array}{l}\text { School achievement and } \\
\text { motivation }\end{array}$ & 3 & Math and language achievement, motivation & & W3, 4 & & \\
\hline Peer status & 1 & Popularity among classmates & & & & W2 \\
\hline Deviant friends & 1 & Crime, truancy, and substance use by two best friends & & & W4 & \\
\hline Relationship sibling(s) & 1 & Relationship with siblings & W2 & & & \\
\hline Role among peers & 4 & Popular, isolated, bullied, dominating & & W3, 4 & & \\
\hline Victimisation & 2 & Victimisation of peer aggression and violence & & & W4 & \\
\hline
\end{tabular}

Table 3. Number of youths who were placed in out-of-home care.

\begin{tabular}{cc}
\hline Ages & Number of youths \\
\hline $11-13$ & $19(1.4 \%)$ \\
$13-15$ & $22(1.5 \%)$ \\
$15-16$ & $19(1.5 \%)$ \\
Total & $47(3.9 \%)$ \\
\hline
\end{tabular}

Note. Individual cells do not sum to 47 due to youths who reported out-of-home placement in multiple waves. 
Figure 1. Histograms of treated and control cases before and after matching (examples from the first imputation, 83 covariates).

a. Full matching

Raw Treated

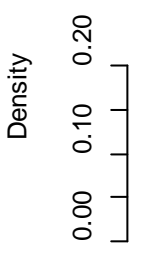

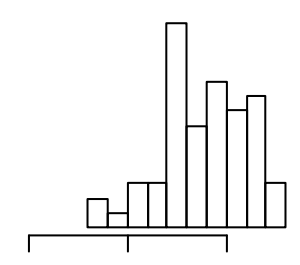

$\begin{array}{lll}-10 & -5 & 0\end{array}$

Propensity Score

Raw Control

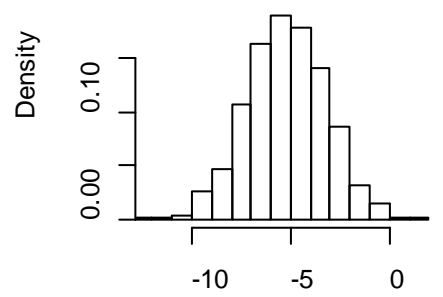

Propensity Score

b. Constrained full matching

Raw Treated<smiles>O=C(CO)C(=O)C1CO1</smiles>

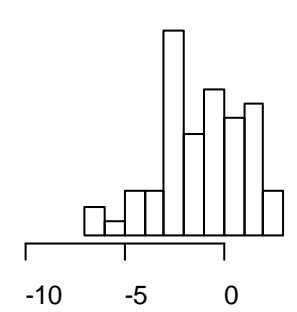

Propensity Score

Raw Control

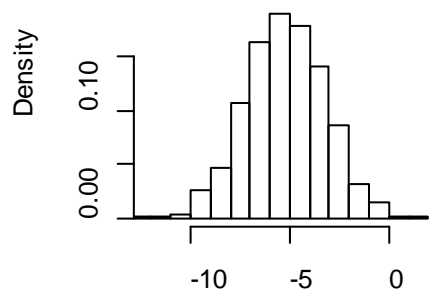

Propensity Score
Matched Treated<smiles>O=C(O)C(=O)CC(O)C1CO1</smiles>

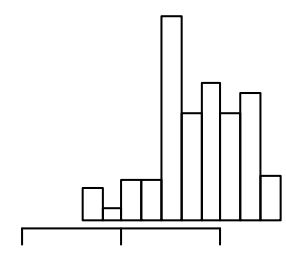

$-10$

Propensity Sco

Matched Control

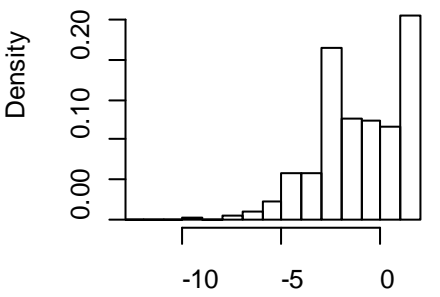

Propensity Sco

Matched Treated

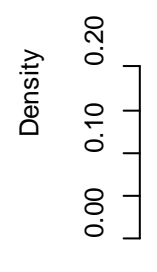

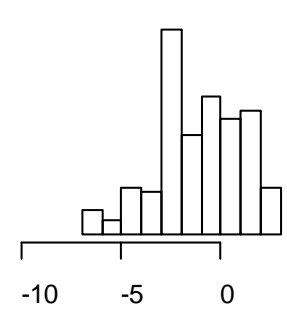

Propensity Sco

Matched Control

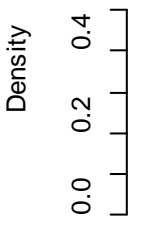

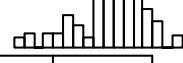

Propensity Sco 
Figure 2. Jitter plot of treated and control cases after matching (examples from the first imputation, 83 covariates).

a. Full matching

\section{Distribution of Propensity Scores}

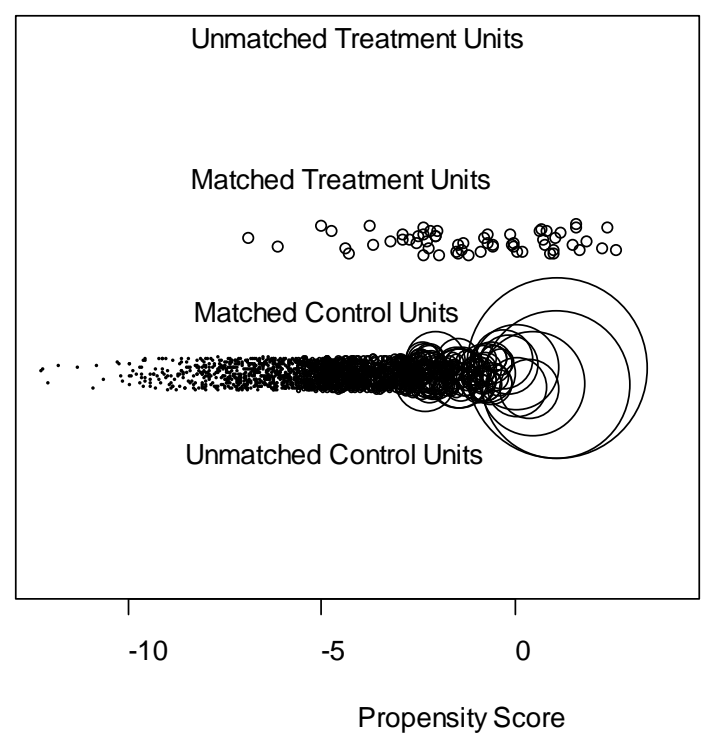

b. Constrained full matching

\section{Distribution of Propensity Scores}

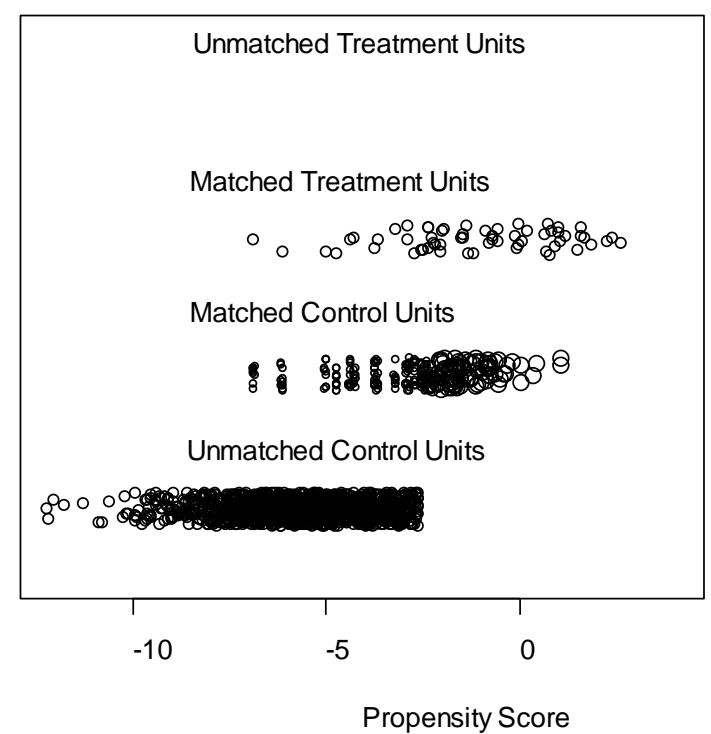


more overlap after matching compared to before, there were several youths placed in out-of-home care on the upper end of the propensity score who had higher propensity scores than any of the youths not placed in out-of-home care, and several youths not placed in out-of-home care on the lower end of the propensity score who had lower propensity scores than any of the youths placed in out-ofhome care. For the full matching method, the jitter plot showed that some of the youths not placed in out-of-home care received a very large weight due to the imbalances.

Second, we examined reductions in the standardised mean difference, which is defined as the weighted difference in means between the two groups divided by the standard deviation in the control (i.e. the youths not placed in out-of-home care) group (Rubin, 2001). If the standardised mean difference is less than 0.25 , matching is considered successful (Ho, Imai, King, \& Stuart, 2007). Only the standardised mean difference for full matching was satisfactory at 0.18 . For constrained full matching, it was 0.51 . Full matching resulted in a $91 \%$ improvement in standardised mean difference compared to the non-matched data; for constrained full matching it was $75 \%$.

Third, we performed weighted $t$-tests on all included covariates after the matching. On average, $32 \%$ of the covariates showed statistically significant differences between the youths who were placed in out-of-home care and those who were not after full matching. After constrained full matching, where only part of the youths not placed in out-of-home care was matched, only $2 \%$ of the tests were significant.

\section{Measures taken to increase common support}

Several measures were taken to increase common support. First, interaction terms with clear imbalances across the two groups were included. This decreased common support.

Next, we decreased the number of covariates used for matching as a large amount of covariates may exacerbate common support issues (Smith \& Todd, 2005). More specifically, we examined $t$-tests of all 83 covariates before matching and matched the data again using subsets of covariates based on different cut-off values of the $t$-statistics (see appendix 1): the first matching procedure only included covariates that exceeded $t>|6|$ prior to matching (resulting in using a subset of four covariates for matching), the second used $t>|5|$ (leading to the inclusion of 12 covariates), the third $t>|4.5|$ (20 covariates), and the fourth $t>|4|$ (26 covariates). As reported in the upper half of table 4, the standardised mean bias was lower when less covariates were included for both full and constrained full matching. We also performed weighted $t$-tests across all 83 covariates after matching and calculated the percentage of $t$-tests that displayed significant differences between the two groups for each of the analyses that included a subset of the covariates. Results are reported in the last column of the upper half of table 4 . The percentage of significant $t$-tests was high for both full and constrained full matching when only four covariates were included. For full matching, the percentage was lowest when 12 and 20 covariates were included. For constrained full matching, the percentage dropped below $5 \%$ at 20 covariates or more, a percentage that could be expected based on chance alone.

Our final measure to increase common support was to discard all cases that were off common support, i.e. outside the range of propensity scores of the other group. Thus, all youths placed in outof-home care with propensity scores that were higher than the highest propensity score in the group of youths not placed in out-of-home care were excluded, as were all youths not placed in outof-home care with propensity scores that were lower than the lowest propensity score in the group of youths placed in out-of-home care. As shown in the lower half of table 4 and as could be expected, this decreased the standardised mean differences. For full matching, especially for larger numbers of covariates, this also decreased the percentage of significant $t$-tests (see the last column of the lower half of table 4). This was less the case for constrained full matching, which had already discarded part of the cases in the earlier part of the matching.

\section{Effects on outcomes}

Given the challenges encountered in the matching procedures, we proceeded to estimate the outcome effects as follows. We first estimated the effects of out-of-home placement using the non-matched data. Next, we estimated the effects using the matched data. We did this both for full and constrained full matching, and using sets of 12 , 20,26 , and 83 covariates separately. Finally, we repeated the analyses discarding all cases that were off common support. 
Table 4. Standardised mean bias and $\%$ of significant $t$-tests after matching.

\begin{tabular}{|c|c|c|c|c|c|c|}
\hline Matching procedure & $\begin{array}{c}\text { Number } \\
\text { of } \\
\text { covariates }\end{array}$ & $\begin{array}{l}\text { Std. Mean } \\
\text { Difference }\end{array}$ & $\begin{array}{c}\text { \% Balance } \\
\text { improveme } \\
\text { nt: Std. } \\
\text { Mean Diff. }\end{array}$ & Matched Control & Matched Treated & $\begin{array}{c}\% \\
\text { significant } \\
t \text {-tests }\end{array}$ \\
\hline Full matching & 4 & 0.01 & 99.12 & 1429 & 54 & $15.3 \%$ \\
\hline Full matching & 12 & 0.00 & 99.41 & 1429 & 54 & $9.5 \%$ \\
\hline Full matching & 20 & 0.02 & 98.75 & 1429 & 54 & $10.2 \%$ \\
\hline Full matching & 26 & 0.03 & 97.99 & 1429 & 54 & $12.3 \%$ \\
\hline Full matching & 83 & 0.18 & 91.18 & 1429 & 54 & $31.7 \%$ \\
\hline Constrained full matching & 4 & 0.10 & 88.81 & 320 & 54 & $19.4 \%$ \\
\hline Constrained full matching & 12 & 0.17 & 84.65 & 332 & 54 & $6.1 \%$ \\
\hline Constrained full matching & 20 & 0.21 & 82.61 & 306 & 54 & $4.7 \%$ \\
\hline Constrained full matching & 26 & 0.24 & 81.22 & 307 & 54 & $2.4 \%$ \\
\hline Constrained full matching & 83 & 0.51 & 74.56 & 227 & 54 & $2.4 \%$ \\
\hline \multicolumn{7}{|c|}{ Cases off common support discarded } \\
\hline Full matching & 4 & 0.01 & 98.90 & 1373 & 54 & $17.5 \%$ \\
\hline Full matching & 12 & 0.01 & 99.44 & 1296 & 54 & $11.1 \%$ \\
\hline Full matching & 20 & 0.00 & 99.83 & 1286 & 52 & $9.5 \%$ \\
\hline Full matching & 26 & 0.00 & 99.88 & 1258 & 50 & $7.7 \%$ \\
\hline Full matching & 83 & 0.01 & 99.59 & 897 & 41 & $5.2 \%$ \\
\hline Constrained full matching & 4 & 0.11 & 87.17 & 317 & 54 & $19.5 \%$ \\
\hline Constrained full matching & 12 & 0.19 & 82.76 & 330 & 54 & $6.1 \%$ \\
\hline Constrained full matching & 20 & 0.14 & 88.83 & 306 & 52 & $3.9 \%$ \\
\hline Constrained full matching & 26 & 0.12 & 90.44 & 304 & 50 & $3.0 \%$ \\
\hline Constrained full matching & 83 & 0.14 & 93.36 & 216 & 41 & $0.0 \%$ \\
\hline
\end{tabular}

Note. Number of treated cases differs from reported in table 3 due to multiple imputation. 
Table 5. Outcomes of regression analyses.

\begin{tabular}{|c|c|c|c|c|c|c|c|c|c|}
\hline \multirow{3}{*}{ Dependent variables } & \multirow{3}{*}{$\begin{array}{c}\text { Non- } \\
\text { matched } \\
\text { data }\end{array}$} & \multicolumn{4}{|c|}{12 covariates } & \multicolumn{4}{|c|}{20 covariates } \\
\hline & & \multicolumn{2}{|c|}{ Full matching } & \multicolumn{2}{|c|}{ Constrained full matching } & \multicolumn{2}{|c|}{ Full matching } & \multicolumn{2}{|c|}{$\begin{array}{l}\text { Constrained full } \\
\text { matching }\end{array}$} \\
\hline & & All cases & $\begin{array}{c}\text { Cases on } \\
\text { common } \\
\text { support }\end{array}$ & All cases & $\begin{array}{c}\text { Cases on } \\
\text { common } \\
\text { support }\end{array}$ & All cases & $\begin{array}{c}\text { Cases on } \\
\text { common } \\
\text { support }\end{array}$ & All cases & $\begin{array}{c}\text { Cases on } \\
\text { common } \\
\text { support }\end{array}$ \\
\hline \multicolumn{10}{|l|}{ Youth outcomes } \\
\hline Delinquency & $0.48^{*}$ & 0.02 & 0.00 & 0.09 & 0.10 & 0.21 & 0.14 & 0.14 & 0.11 \\
\hline Aggression & $0.20 * *$ & 0.01 & 0.00 & 0.04 & 0.04 & -0.01 & -0.01 & 0.05 & 0.03 \\
\hline Police contacts & $1.53^{* *}$ & 0.18 & 0.32 & 0.56 & 0.66 & 0.49 & 0.34 & 0.68 & 0.54 \\
\hline Substance use & $0.72 * *$ & $0.46+$ & $0.53^{*}$ & $0.50+$ & $0.55^{+}$ & 0.43 & 0.42 & 0.45 & 0.45 \\
\hline Optimism & -0.09 & 0.03 & 0.02 & -0.02 & -0.02 & 0.03 & 0.02 & 0.00 & -0.01 \\
\hline Anxiety \& depression & 0.16 & 0.14 & 0.16 & 0.13 & 0.15 & 0.09 & 0.08 & 0.08 & 0.08 \\
\hline Suicidal ideation & $0.95^{*}$ & 0.77 & 0.87 & 0.56 & 0.61 & 0.46 & 0.47 & 0.46 & 0.49 \\
\hline Low education & $0.75^{* *}$ & 0.36 & 0.36 & 0.33 & 0.32 & 0.37 & 0.32 & 0.38 & 0.36 \\
\hline School commitment & 0.01 & 0.11 & 0.09 & 0.08 & 0.07 & 0.11 & 0.09 & 0.09 & 0.08 \\
\hline Generalised trust & -0.08 & 0.08 & 0.08 & 0.02 & 0.02 & 0.02 & 0.03 & 0.04 & 0.05 \\
\hline Self-efficacy & -0.05 & 0.01 & -0.01 & -0.02 & -0.03 & -0.01 & -0.01 & -0.04 & -0.03 \\
\hline
\end{tabular}


Table 5. Continued. Outcomes of regression analyses.

\begin{tabular}{|c|c|c|c|c|c|c|c|c|}
\hline \multirow{3}{*}{ Dependent variables } & \multicolumn{4}{|c|}{26 covariates } & \multicolumn{4}{|c|}{83 covariates } \\
\hline & \multicolumn{2}{|c|}{ Full matching } & \multicolumn{2}{|c|}{ Constrained full matching } & \multicolumn{2}{|c|}{ Full matching } & \multicolumn{2}{|c|}{$\begin{array}{c}\text { Constrained full } \\
\text { matching }\end{array}$} \\
\hline & All cases & $\begin{array}{c}\text { Cases on } \\
\text { common } \\
\text { support }\end{array}$ & All cases & $\begin{array}{l}\text { Cases on } \\
\text { common } \\
\text { support }\end{array}$ & All cases & $\begin{array}{l}\text { Cases on } \\
\text { common } \\
\text { support }\end{array}$ & All cases & $\begin{array}{c}\text { Cases on } \\
\text { common } \\
\text { support }\end{array}$ \\
\hline \multicolumn{9}{|l|}{ Youth outcomes } \\
\hline Delinquency & 0.18 & 0.15 & 0.14 & 0.12 & 0.42 & 0.19 & 0.31 & 0.28 \\
\hline Aggression & -0.04 & -0.05 & 0.04 & 0.01 & 0.01 & -0.04 & 0.10 & 0.01 \\
\hline Police contacts & 0.42 & 0.56 & 0.73 & 0.60 & 1.27 & 0.58 & 0.96 & 0.47 \\
\hline Substance use & 0.35 & 0.50 & $0.50+$ & $0.54+$ & 0.55 & $0.65+$ & $0.60+$ & $0.72 \dagger$ \\
\hline Optimism & 0.04 & 0.01 & 0.00 & 0.00 & 0.00 & -0.03 & -0.04 & -0.07 \\
\hline Anxiety \& depression & 0.06 & 0.11 & 0.08 & 0.08 & 0.04 & 0.05 & 0.04 & 0.07 \\
\hline Suicidal ideation & 0.25 & 0.46 & 0.44 & 0.45 & 0.72 & 0.45 & 0.69 & 0.68 \\
\hline Low education & 0.31 & 0.27 & 0.34 & 0.28 & 0.49 & 0.23 & $0.46+$ & 0.26 \\
\hline School commitment & 0.11 & 0.06 & 0.08 & 0.06 & 0.02 & 0.05 & 0.02 & -0.01 \\
\hline Generalised trust & 0.03 & 0.05 & 0.04 & 0.05 & -0.05 & -0.03 & 0.01 & 0.00 \\
\hline Self efficacy & -0.01 & -0.02 & -0.04 & -0.04 & 0.04 & 0.04 & 0.00 & 0.03 \\
\hline
\end{tabular}

Note. Unstandardised coefficients. Due to varying distributional properties of the dependent variables, we used a negative binomial model to estimate the regression for delinquency, a tobit model for suicidal ideation, and logit models for psychiatric clinic and all three variables for police contacts. The remaining regressions were estimated using linear models.

$+p<.10 ;{ }^{*} p<.05 ;{ }^{*} p<.01$ 
Results are shown in table 5 . As shown in the first results column (named 'Non-matched data'), out-of-home placement was related to several of the dependent variables prior to matching, with youths who were placed in out-of-home care displaying heightened levels of delinquency, aggression, police contacts, substance use, and suicidal ideation, while having lower education.

Results for the matched data, however, indicate that these problematic outcomes were primarily due to selection effects, i.e. youths placed in out-ofhome care coming from more problematic backgrounds and displaying problem behaviour already prior to out-of-home placement. In fact, once youths placed in out-of-home care were matched to youths who were not placed in out-ofhome care but were from similar backgrounds and displayed the same types of behaviour, few significant relations remained. In one of the analyses (full matching on 12 covariates, only cases on common support included), youths placed in out-of-home care were more likely to use substances, but this effect was not stable across the analyses.

\section{Supplementary analyses}

In our final set of analyses, we examined whether the results of our analyses were robust, by combining two supplementary analyses. First, due to the shown challenge of including a large number of covariates in the matching procedure, we used an alternative method to reduce the number of covariates, namely through exploratory factor analysis using the principle-axis factor extraction. Factor loadings are presented in appendix 2 . The analysis indicated a 21-factor structure with sums of squared loadings ranging from 1.3 to 5.0.

Second, in the analyses presented so far, we relied on an estimation of the propensity scores using logistic regression, which assumes a linear relation between the propensity score and its predictors. Generalized Boosted Modeling (GBM) relaxes this assumption, using regression trees and iterative algorithms to create complex models by combining multiple simple models (Olmos \& Govindasame, 2015), thereby helping to solve the variable specification problem and potentially leading to a more accurate prediction of treatment probability (Guo \& Fraser, 2010; McCaffrey, Ridgeway, \& Morral, 2004). We therefore performed GBM to estimate the propensity scores, using the 21 factors extracted through the EFA and the twang package in R (Ridgeway, McCaffrey, Morral, Burgette, \& Griffin, 2017). Balance statistics are presented in appendix 3. Outcome analyses displayed in table 6 indicated one significant difference between the out-of-home care and the non-out-of-home care group, namely that the former reported higher levels of anxiety and depression at age 17 compared to the latter. The other differences between the two groups were not statistically significant.

\section{Discussion}

Children and youths who are placed in out-ofhome care often experience unfavourable outcomes later in life. It is unknown, however, whether this is due to the out-of-home placement itself or to the pre-existing difficulties that these children and youths face. In this paper, we examined the effects of out-of-home placement on youth outcomes at age 17 using a large representative longitudinal sample of youths from Zurich, Switzerland and a propensity score matching approach using covariates collected among multiple informants to reduce selection bias. A substantial minority, namely $3.9 \%$ of the participants, experienced at least one episode of out-of-home placement between the ages 11 and 16 .

Our findings suggest, first, that adolescents placed in out-of-home care displayed substantially higher risk levels in childhood across a range of domains including family background, problem behaviour, and school problems compared to youths who were not placed in out-of-home-care. The difference in backgrounds and behaviour between the two groups was found to be so large that it complicated the propensity score matching analysis to the extent that it proved difficult to match the two groups properly and several additional measures had to be taken to examine the robustness of the results.

Second, the results of the analyses show that most of the differences in outcomes between youths who were placed in out-of-home care and those who were not are likely due to pre-existent differences between the two groups, and not to the out-of-home placement itself. More specifically, even though youths placed in out-of-home care displayed significantly more externalising and internalising problem behaviour and had lower education at age 17 compared to youths not placed in out-of-home care, almost all of these differences disappeared after matching. The only effects that 
Table 6. Outcome regressions based on PSM using Generalised Boosted Models.

\begin{tabular}{ll}
\hline & $\begin{array}{l}\text { Unstandardised } \\
\text { coefficient }\end{array}$ \\
\hline Youth outcomes & \\
Delinquency & 0.08 \\
Aggression & 0.03 \\
Police contacts & 0.02 \\
Substance use & 0.63 \\
Optimism & -0.21 \\
Anxiety \& depression & $0.48^{*}$ \\
Suicidal ideation & 0.51 \\
Low education & 0.28 \\
School commitment & 0.03 \\
Generalised trust & -0.08 \\
Self efficacy & -0.02 \\
\hline tp $<.10 ;{ }^{*} p<.05 ; * *<.01$
\end{tabular}

remained (on substance use and anxiety and depression) were unstable across the analyses.

The overall lack of effects of out-of-home placement on youth outcomes suggests that out-of-home placement may not have negative consequences. However, our results should be seen in the context of our study and sample. First, the outcomes were measured on average about three (with a range of one to five) years after the placement. Hence, our results may not be representative of shorter-term effects or delayed effects into adulthood. Second, our study was conducted among adolescents in Switzerland, and the results may not be generalisable to younger children or other countries. Finally, it should be noted that our findings do not imply that youths who are placed in out-of-home care do not face adversity. To the contrary, as our analyses showed, their backgrounds were disproportionately problematic. Our results suggest that out-of-home placement did not worsen their situation, but, as is widely recognised, these youths nevertheless require significant support services to overcome the obstacles they are presented with.

Although few negative effects of the out-ofhome placement itself were observed, our findings also suggest little evidence for improved youth outcomes. Although quite some efforts have been made in the past years to improve the quality of foster care in Switzerland, one additional way to potentially improve outcomes for youths placed in out-ofhome care could be to integrate structured intensive and individualised support systems into the out-of-home placement. So-called therapeutic foster care programs that provide foster parents with the skills needed to manage and change challenging behaviour have been shown to be capable of decreasing externalising and internalising behavioural problems and improving school engagement and employment (Chamberlain et al., 2008; Knorth, Harder, Zandberg, \& Kendrick, 2008; Reddy \& Pfeiffer, 1997; Macdonald \& Turner, 2008; Westermark et al., 2011), although this may not extend to all child protection systems (Biehal et al., 2012; Biehal, Ellison, \& Sinclair, 2012).

Our study was subject to several limitations. First, we did not have data on the type of outof-home placement (institutions versus family) that the youths were placed in. This limits the conclusions that can be drawn from our study as these variables may play an important role in determining youth outcomes. Indeed, research indicates that placement in a residential institution is related to less favourable outcomes compared to foster families (see Vanderfaellie et al., 2015). Future research that distinguishes between youths placed in institutions and families using a propensity score matching approach is highly recommended. Second, our data were limited in other aspects of the foster care placement as well. We did not have data on the foster 
caregivers, the out-of-home care environment, the reasons for placement, premature breakdown of the out-of-home placement, or length of stay in the out-of-home situation. These factors play an important role in predicting later life success and the absence of information on these aspects limits our study. Future work that focuses on these aspects specifically is highly recommended. Third, the number of out-of-home placements in our sample was only small and therefore the two groups in our analysis (i.e. out-of-home care youths and non-out-of-home care youths) were unbalanced. Although supplementary analyses using GBM were conducted to partially account for this issue, future analyses using larger samples are recommended. Fourth, our dependent variables were measured through youth reports only. Since different informants may have differing views on the same phenomenon and results may depend on the informant of the behaviour (Schmid et al., 2013;
Van Oijen, 2010), future studies including perspectives of different informants would be helpful. Fifth, we did not examine moderator effects. Given that the effects of out-of-home placement may vary among youths, for example according to their initial level of problem behaviour (Newton et al., 2000; Schmid et al., 2013), as well as age, such analyses are encouraged.

Although there are many research questions that need to be tackled by future research, this study contributed to our knowledge by using data from a large population study combined with a propensity score matching approach to estimate the outcomes of out-of-home placement at age 17. It showed that although research on the effects of out-of-home care is not without challenges due to the highly problematic backgrounds of youths placed in out-of-home care, the results were fairly consistent in showing very few effects (negative or positive) of the out-of-home placement itself.

\section{Acknowledgements}

The research reported in this manuscript was financially supported by the Swiss National Science Foundation, the Jacobs Foundation, the Swiss Federal Office of Public Health, the Canton of Zurich Ministry of Education, and the Julius Baer Foundation. The authors would like to express their sincere thanks to the youths, parents, and teachers participating in the study. Moreover, the authors are grateful to the interviewers and undergraduate students for their help in data collection and coding.

\section{References}

Allison, P. (2001). Missing data. Thousand Oaks, CA: Sage.

Apel, R. J., \& Sweeten, G. (2010). Propensity score matching in criminology and criminal justice. In A. R. Piquero, \& D. Weisburd (Eds.), Handbook of quantitative criminology (pp. 543-562). Springer New York. https://doi.org/10.1007/978-0-387-77650-7 26

Arnett, J. J. (2000). Emerging adulthood: A theory of development from the late teens through the twenties. American psychologist, 55(5), 469. https://doi.org/10.1037/0003-066X.55.5.469

Averdijk, M., Zirk-Sadowski, J., Ribeaud, D., \& Eisner, M. (2016). Long-term effects of two childhood psychosocial interventions on adolescent delinquency, substance use, and antisocial behavior: a cluster randomized controlled trial. Journal of Experimental Criminology, 12(1), 21-47. https://doi.org/10.1007/s11292-015-9249-4

Barber, J., \& Delfabbro, P. (2005). Children's adjustment to long-term foster care. Children and Youth Services Review, 27(3), 329-340. https://doi.org/10.1016/i.childyouth.2004.10.010

Baumeister, R. F., \& Leary, M. R. (1995). The need to belong: desire for interpersonal attachments as a fundamental human motivation. Psychological bulletin, 117(3), 497.

https://doi.org/10.1037/0033-2909.117.3.497 
Bendixen, M., Endresen, I. M., \& Olweus, D. (2003). Variety and frequency scales of antisocial involvement: Which one is better? Legal and Criminological Psychology, 8(2), 135-150. https://doi.org/10.1348/135532503322362924

Berzin, S. C. (2008). Difficulties in the transition to adulthood: Using propensity scoring to understand what makes foster youth vulnerable. Social Service Review, 82(2), 171-196. https://doi.org/10.1086/588417

Biehal, N., Dixon, J., Parry, E., Sinclair, I., Greenlaw, J., Roberts, C., ... Roby, A. (2012). The care placements evaluation (CaPE) evaluation of multidimensional treatment foster care for adolescents (MTFC-A) (Research report DFE-RR194). Department for Education.

Biehal, N., Ellison, S. \& Sinclair, I. (2012). Intensive fostering: An independent evaluation of MTFC in an English setting. Adoption \& Fostering, 36, 13-26. https://doi.org/10.1177/030857591203600104

Biehal, N., \& Wade, J. (1996). Looking back, looking forward: Care leavers, families and change. Children and youth services review, 18(4), 425--445. https://doi.org/10.1016/0190-7409(96)00013-8

Blome, W. W. (1997). What happens to foster kids: Educational experiences of a random sample of foster care youth and a matched group of non-foster care youth. Child and Adolescent Social Work Journal, 14(1), 41-53. https://doi.org/10.1023/A:1024592813809

Blülle, S. (2013). Kinder und Jugendliche platzieren: Ein Handlungsleitfaden für platzierungsbegleitende Fachpersonen. In Integras (Eds.). Leitfaden Fremdplazierung, pp. 1069. Zürich: Integras.

Chamberlain, P., Price, J., Leve, L. D., Laurent, H., Landsverk, J. A., \& Reid, J. B. (2008). Prevention of behavior problems for children in foster care: Outcomes and mediation effects. Prevention Science, 9, 17-27. https://doi.org/10.1007/s11121-007-0080-7

Clausen, J. M., Landsverk, J., Ganger, W., Chadwick, D., Litrownik, A. (1998). Mental health problems of children in foster care. Journal of Child and Family Studies, 7, 283-96. https://doi.org/10.1023/A:1022989411119

Cook, R. J. (1994). Are we helping foster care youth prepare for their future?. Children and Youth Services Review, 16(3-4), 213-229. https://doi.org/10.1016/0190-7409(94)90007-8

Courtney, M. E., \& Dworsky, A. (2006). Early outcomes for young adults from out-of-home care in the USA. Child \& Family Society Work, 11(3), 209-219. https://doi.org/10.1111/j.13652206.2006.00433.x

Courtney, M. E., \& Heuring, D. H. (2005). The transition to adulthood for youth "aging Out" Of The Foster Care System. In D. W. Osgood, E. M. Foster, C. Flanagan \& G. Ruth (Eds.), On your own without a net: The transition to adulthood for vulnerable populations (pp. 27-67). Chicago, IL: University of Chicago Press.

Courtney, M. E., Okpych, N. J., Charles, P., Mikell, D., Stevenson, B., Park, K., ... \& Okpych, N. J. (2016). Findings from the California Youth Transitions to Adulthood Study (CalYOUTH): Conditions of Youth at Age 19. Chicago, IL: Chapin Hall at the University of Chicago.

Danese, A., \& McEwen, B. S. (2012). Adverse childhood experiences, allostasis, allostatic load, and age-related disease. Physiology \& Behavior, 106(1), 29-39. https://doi.org/10.1016/j.physbeh.2011.08.019

dosReis, S., Zito, J. M., Safer, D. J., \& Soeken, K. L. (2001). Mental health services for youths in foster care and disabled youths. American Journal of Public Health, 91(7), 1094. https://doi.org/10.2105/AJPH.91.7.1094

Dworsky, A. (2005). The economic self-sufficiency of Wisconsin's former foster youth. Children and Youth Services Review, 27(10), 1085-1118. https://doi.org/10.1016/j.childyouth.2004.12.032

Eisner, M. P., Malti, T., \& Ribeaud, D. (2011). Large-scale criminological field experiments. Sage handbook of criminological research methods, 410-424.

Eisner, M., Nagin, D., Ribeaud, D., \& Malti, T. (2012). Effects of a universal parenting program for highly adherent parents: a propensity score matching approach. Prevention Science, 13(3), 252-266. https://doi.org/10.1007/s11121-011-0266-x 
Federal Statistical Office (2010-2015). Statistik der Bevölkerung und der Haushalte (STATPOP). Neuchâtel.

Ganzel, B. L., Morris, P. A., \& Wethington, E. (2010). Allostasis and the human brain: Integrating models of stress from the social and life sciences. Psychological Review, 117(1), 134. https://doi.org/10.1037/a0017773

Gassman, Y. R. (2008). Pflegeeltern und ihre Pflegekinder. Münster: Waxmann Verlag.

Gassman, Y. R. (2013). Diversität in der Pflegekinderhilfe. In E.M. Piller \& S. Schnurr (Eds.), Kinderund Jugendhilfe in der Schweiz: Forschung und Diskurse (pp. 129-161). Wiesbaden: Springer VS. https://doi.org/10.1007/978-3-531-19061-7 6

Guo, S., \& Fraser, M. W. (2010). Propensity score analysis: Statistical methods and applications. Sage Publications.

Hansen, B. B. (2004). Full matching in an observational study of coaching for the SAT. Journal of the American Statistical Association, 99, 609-618. https://doi.org/10.1198/016214504000000647

Herman, D. B., Susser, E. S., Struening, E. (1994). Childhood out-of-home care and current depressive symptoms among homeless adults. American Journal of Public Health 1994;84:1849-51. https://doi.org/10.2105/AJPH.84.11.1849

Ho, D. E., Imai, K., King, G., \& Stuart, E. A. (2007). Matching as nonparametric preprocessing for reducing model dependence in parametric causal inference. Political analysis, 15(3), 199-236. https://doi.org/10.1093/pan/mpl013

Ho, D. E., Imai, K., King, G., \& Stuart, E. A. (2011). Matchit: Nonparametric preprocessing for parametric causal inference. Downloaded July 2016 from http://r.iq.harvard.edu/docs/matchit/2.4-20/matchit.pdf https://doi.org/10.18637/jss.v042.i08

Holland, P., and Gorey, K. M. (2004). Historical, developmental, and behavioral factors associated with foster care challenges. Child and Adolescent Social Work Journal, 21(2), 117-135. https://doi.org/10.1023/B:CASW.0000022727.40123.95

Huwiler, K., Raulf, B., Tanner, H., Wicki, T., and Arnold, C. (2008). Pflegefamilien- und Heimplatzierungen. Eine empirische Studie über den Hilfeprozess und die Partizipation von Eltern und Kindern. Zürich: Rüegger.

Integras (2013). Leitfaden Fremdplazierung. Zürich: Integras.

Integras (2016). Label FPO Integras: Zwei Institutionen sind neu zertifiziert. http://www.integras.ch/de/aktuelles/274-label-fpo-integras-zwei-institutionen-sind-neuzertifiziert-wir-gratulieren

Jung, H., \& LaLonde, R. (2016). The relationship between re-incarceration and their own childhood foster care experience of women. Children and Youth Services Review, 62, 40-48. https://doi.org/10.1016/i.childyouth.2016.01.013

Keller, A. (2012). Familienplatzierungs-Organisationen in der Schweiz: Bericht zuhanden der Konferenz der kantonalen Sozialdirektorinnen und Sozialdirektoren. Downloaded July 2016: http://www.integras.ch/images/ pdf/themenmenu/sozial sonderpaedagogik/familienplatzie rungsorganisationen/2012 FPOinderSchweiz BerichtfuerSODK de.pdf

Knorth, E. J., Harder, A. T., Zandberg, T. \& Kendrick, A. J. (2008). Under one roof: A review and selective meta-analysis on the outcomes of residential child and youth care. Children and Youth Services Review, 30, 123-140. https://doi.org/10.1016/j.childyouth.2007.09.001

Kortenkamp, K., \& Ehrle, J. (2002). The well-being of children involved with the child welfare system: A national overview. The Urban Institute B (B-43) (Retrieved from http://www.urban.org/UploadedPDF/310413 anf b43.pdf).

Lambert, N. M., Stillman, T. F., Hicks, J. A., Kamble, S., Baumeister, R. F., \& Fincham, F. D. (2013). To belong is to matter: Sense of belonging enhances meaning in life. Personality and Social Psychology Bulletin, 39(11), 1418-1427. https://doi.org/10.1177/0146167213499186 
Lee, J. S. (2012). The role of institutions in the transition to adulthood and their impact on pathways to adulthood and adult criminal outcomes. Unpublished Dissertation. University of Washington.

Love, L.T., McIntosh, J., Rost, M., \& Tertzakian, K. (2005). Fostering hope: Preventing teen pregnancy among youth in foster care. Washington, DC: National Campaign to Prevent Teen Pregnancy

Macdonald, G. \& Turner, W. (2008). Treatment Foster Care for improving outcomes in children and young people. The Cochrane Library, 1, 1-53. https://doi.org/10.1002/14651858.CD005649.pub2

Malti, T., Ribeaud, D., \& Eisner, M. P. (2011). The effectiveness of two universal preventive interventions in reducing children's externalizing behavior: a cluster randomized controlled trial. Journal of Clinical Child \& Adolescent Psychology, 40(5), 677-692. https://doi.org/10.1080/15374416.2011.597084

McCaffrey, D. F., Ridgeway, G., \& Morral, A. R. (2004). Propensity score estimation with boosted regression for evaluating causal effects in observational studies. Psychological Methods, 9(4), 403. https://doi.org/10.1037/1082-989X.9.4.403

McCord, J., Mc Cord, W., \& Thurber, E. (1960). The effects of foster-home placement in the prevention of adult antisocial behavior. Social Service Review, 34(4), 415-420. https://doi.org/10.1086/640927

McEwen, B. S. (1998). Stress, adaptation, and disease: Allostasis and allostatic load. Annals of the New York Academy of Sciences, 840(1), 33-44. https://doi.org/10.1111/j.1749-6632.1998.tb09546.x

Mortimer, J. T., \& Larson, R. W. (Eds.). (2002). The changing adolescent experience: Societal trends and the transition to adulthood. Cambridge University Press.

https://doi.org/10.1017/CBO9780511613913

Netzwerk IPK (2013). Qualitätsstandard für institutionelle Pflegeplätze.

Newton, R. R., Litrownik, A. J., \& Landsverk, J. A. (2000). Children and youth in foster care: Disentangling the relationship between problem behaviors and number of placements. Child Abuse \& Neglect, 24(10), 1363-1374. https://doi.org/10.1016/S0145-2134(00)00189-7

Obsuth, I., Murray, A. L., Malti, T., Sulger, P., Ribeaud, D., \& Eisner, M. (2016). A Non-bipartite Propensity Score Analysis of the Effects of Teacher-Student Relationships on Adolescent Problem and Prosocial Behavior. Journal of Youth and Adolescence, 1-27.

Okpych, N. J., \& Courtney, M. E. (2014). Does education pay for youth formerly in foster care? Comparison of employment outcomes with a national sample. Children and Youth Services Review, 43, 18-28. https://doi.org/10.1016/j.childyouth.2014.04.013

Olmos, A., \& Govindasamy, P. (2015). A Practical Guide for Using Propensity Score Weighting in R. Practical Assessment, Research \& Evaluation, 20.

Osgood, D. W., Foster, E. M., Flanagan, C., and Ruth, G. R. (Eds.). (2005). On your own without a net: The transition to adulthood for vulnerable populations. Chicago II: University of Chicago Press. https://doi.org/10.7208/chicago/9780226637853.001.0001

Ossipow, L., Aeby, G., \& Berthod, M. A. (2013). Die Trugbilder des Erwachsenenlebens: Ethnographie des Erlernens von Autonomie in den sozialpädagogischen Einrichtungen für Minderjährige. In E. M. Piller \& S. Schnurr (Eds.), Forschungsbeiträge zur Kinder-und Jugendhilfe in der Schweiz: Forschung und Diskurse, (pp. $101-128)$. Wiesbaden: Springer Verlag. https://doi.org/10.1007/978-3-531-19061-7 5

Palmer, S. E. (1976). Children in Long Term Care. Their Experiences and Progress. Canada: Family and Children's Services of London and Middlesex.

Park, J. M., Metraux, S., \& Culhane, D. P. (2005). Childhood out-of-home placement and dynamics of public shelter utilization among young homeless adults. Children and Youth Services Review, 27(5), 533-546. https://doi.org/10.1016/j.childyouth.2004.10.001 
Pecora, P. J., Kessler, R. C., O'Brien, K., White, C. R., Williams, J., Hiripi, E., ... \& Herrick, M. A. (2006). Educational and employment outcomes of adults formerly placed in foster care: Results from the Northwest Foster Care Alumni Study. Children and youth services review, 28(12), 14591481. https://doi.org/10.1016/j.childyouth.2006.04.003

Pilowsky, D. J., \& Wu, L. T. (2006). Psychiatric symptoms and substance use disorders in a nationally representative sample of American adolescents involved with foster care. Journal of Adolescent Health, 38(4), 351-358. https://doi.org/10.1016/j.jadohealth.2005.06.014

Reddy, L. A. \& Pfeiffer, S. I. (1997). Effectiveness of treatment foster care with children and adolescents: A review of outcome studies. Journal of the American Academy of Child \& Adolescent Psychiatry, 36, 581-588. https://doi.org/10.1097/00004583-199705000-00007

Ridgeway, G., McCaffrey, D., Morral, A., Burgette, L., \& Griffin, B. A. (2017). Toolkit for Weighting and Analysis of Nonequivalent Groups: A tutorial for the twang package. Santa Monica, CA: RAND Corporation.

Roberts, J., and Horney, J. (2010). The life event calendar method in criminological research. In A. R. Piquero \& D. Weisburd (Eds.), Handbook of Quantitative Criminology, (pp. 289-312). New York, NY: Springer. https://doi.org/10.1007/978-0-387-77650-7 15

Rosenfeld, A. A., Pilowsky, D. J., Fine, P., Thorpe, M., Fein, E., Simms, M. D., ... \& Nickman, S. (1997). Foster care: An update. Journal of the American Academy of Child \& Adolescent Psychiatry, 36(4), 448-457. https://doi.org/10.1097/00004583-199704000-00006

Rosenbaum, P. R., \& Rubin, D. B. (1984). Reducing bias in observational studies using subclassification on the propensity score. Journal of the American Statistical Association, 79(387), 516-524. https://doi.org/10.1080/01621459.1984.10478078

Ross, M. E., Kreider, A. R., Huang, Y. S., Matone, M., Rubin, D. M., \& Localio, A. R. (2015). Propensity score methods for analyzing observational data like randomized experiments: challenges and solutions for rare outcomes and exposures. American Journal of Epidemiology, 181(12), 989995. https://doi.org/10.1093/aje/kwu469

Rubin, D. B. (2001). Using propensity scores to help design observational studies: application to the tobacco litigation. Health Services and Outcomes Research Methodology, 2(3-4), 169-188. https://doi.org/10.1023/A:1020363010465

Ryan, J. P., \& Testa, M. F. (2005). Child maltreatment and juvenile delinquency: Investigating the role of placement and placement instability. Children and Youth Services Review, 27(3), 227-249. https://doi.org/10.1016/i.childyouth.2004.05.007

Samuels, G.M. (2008). A reason, a season, or a lifetime: Relational permanence among young adults with foster care backgrounds. Chicago, II: Chapin Hall Center for Children at the University of Chicago.

Schaffner, D. \& Rein, A. (2013). Jugendliche aus einem Sonderschulheim auf dem Weg in die Selbständigkeit - Übergänge und Verläufe. Anregungen für die Heimpraxis aus der Perspektive von Adressat/innen. In E. M. Piller \& S. Schnurr (Eds.), Forschungsbeiträge zur Kinder-und Jugendhilfe in der Schweiz: Forschung und Diskurse, (pp. 53-78). Wiesbaden: Springer Verlag. https://doi.org/10.1007/978-3-531-19061-7 3

Schmid, M., Kölch, Fegert, J., and Schmeck, K. (2013). Abschlussbericht für den Fachausschuss für die Modellversuche und das Bundesamt für Justiz. Zusammenfassung der wichtigsten Ergebnisse und Erkenntnisse des Modellversuchs Abklärung und Zielerreichung in stationären Massnahmen (MAZ.). Basel: Universitäre Psychiatrische Kliniken.

Smith, J. A., \& Todd, P. E. (2005). Does matching overcome LaLonde's critique of non-experimental estimators? Journal of Econometrics, 125, 305-353.

https://doi.org/10.1016/i.jeconom.2004.04.011

StataCorp (2011). Stata Statistical Software: Release 12. College Station, TX: StataCorp LP.

Stillman, T. F., \& Baumeister, R. F. (2009). Uncertainty, belongingness, and four needs for meaning. Psychological Inquiry, 20(4), 249-251. https://doi.org/10.1080/10478400903333544 
Stuart, E. A., \& Green, K. M. (2008). Using full matching to estimate causal effects in nonexperimental studies: examining the relationship between adolescent marijuana use and adult outcomes. Developmental psychology, 44(2), 395. https://doi.org/10.1037/0012-1649.44.2.395

Sweeten, G. (2012). Scaling criminal offending. Journal of Quantitative Criminology, 28, 533-557. https://doi.org/10.1007/s10940-011-9160-8

Taussig, H. N. (2002). Risk behaviors in maltreated youth placed in foster care: A longitudinal study of protective and vulnerability factors. Child Abuse \& Neglect, 26(11), 1179-1199. https://doi.org/10.1016/S0145-2134(02)00391-5

Tremblay, R. E., Loeber, R., Gagnon, C., Charlebois, P., Larivee, S., \& LeBlanc, M. (1991). Disruptive boys with stable and unstable high fighting behavior patterns during junior elementary school. Journal of Abnormal Child Psychology, 19(3), 285-300. https://doi.org/10.1007/BF00911232

Vanderfaeillie, J., Pijnenburg, H., Damen, H., \& van Holen, F. (2015). Foster care assessment: A study of the placement decision process in Flanders. Child Abuse \& Neglect, 49, 119-127. https://doi.org/10.1016/i.chiabu.2015.04.002

van Oijen, S. V. (2010). Resultaat van pleegzorgplaatsingen: een onderzoek naar breakdown en de ontwikkeling van adolescentepleegkinderen bij langdurige pleegzorgplaatsingen Groningen: s.n.

Westermark, P. K., Hansson, K. \& Olsson, M. (2011). Multidimensional treatment foster care (MTFC): Results from an independent replication. Journal of Family Therapy, 33, 20-41. https://doi.org/10.1111/j.1467-6427.2010.00515.x

Wetzels, P., Enzmann, D., Mecklenburg, E., \& Pfeiffer, C. (2001). Jugend und Gewalt. Eine repräsentative Dunkelfeldanalyse in München und acht anderen deutschen Städten. BadenBaden: Nomos.

Wu, L. T., Pilowsky, D. J., \& Schlenger, W. E. (2004). Inhalant abuse and dependence among adolescents in the United States. Journal of the American Academy of Child \& Adolescent Psychiatry, 43(10), 1206-1214. https://doi.org/10.1097/01.chi.0000134491.42807.a3

Zatti, K. B. (2005). Das Pflegekinderwesen in der Schweiz. Analyse, Qualitätsentwicklung und Professionalisierung. Expertenbericht im Auftrag des Bundesamtes für Justiz.

\section{Endnotes}

1. We note that two other available measures for police contacts in the dataset were not used for the current paper because they included police contacts in the past two years and therefore overlapped with the predictor. 


\section{Appendix}

Appendix 1. Differences between youths who were placed in out-of-home care and those who were not.

Results of t-tests on all covariates.

\begin{tabular}{|c|c|c|c|}
\hline & $\begin{array}{l}\text { Youths not placed in } \\
\text { out-of-home care } \\
\qquad M(S D)\end{array}$ & $\begin{array}{c}\text { Youths placed in } \\
\text { out-of-home care } \\
M(S D)\end{array}$ & $t$ statistic \\
\hline Sex & $1.49(.01)$ & $1.57(.07)$ & -0.96 \\
\hline TP1 Parental education PR & $6.45(.08)$ & $5.22(.40)$ & 3.04 \\
\hline TP1 Socioeconomic status PR & $47.85(.50)$ & $39.50(2.44)$ & 3.15 \\
\hline TP1 Financial problems PR & $.07(.01)$ & $.29(.05)$ & -7.59 \\
\hline TP1 Single parent household PR & $.24(.01)$ & $.58(.06)$ & -5.82 \\
\hline TP1 Number of household members PR & $2.06(.03)$ & $1.67(.14)$ & 2.88 \\
\hline TP1 Parental criminality PR & $.04(.01)$ & $.23(.05)$ & -6.59 \\
\hline TP1 Age mother at birth child PR & $30.40(.14)$ & $28.03(.58)$ & 3.29 \\
\hline TP3 Aggression TR & $.55(.02)$ & $.84(.11)$ & -3.32 \\
\hline TP3 Indirect aggression TR & $.69(.02)$ & $1.24(.16)$ & -4.62 \\
\hline TP3 ADHD TR & $1.05(.03)$ & $1.50(.14)$ & -3.31 \\
\hline TP3 Oppositional defiant disorder TR & $.50(.02)$ & $.90(.14)$ & -3.70 \\
\hline TP3 Non-aggressive conduct disorder TR & $.23(.01)$ & $.50(.10)$ & -4.41 \\
\hline TP3 Prosocial behaviour TR & $2.41(.02)$ & $2.23(.11)$ & 1.56 \\
\hline TP3 Anxiety and depression TR & $.82(.02)$ & $1.30(.11)$ & -4.74 \\
\hline TP3 Aggression TR & $.48(.02)$ & $.94(.10)$ & -5.33 \\
\hline TP4 ADHD TR & $1.06(.03)$ & $1.72(.14)$ & -4.89 \\
\hline TP4 Oppositional defiant disorder TR & $.41(.02)$ & $.83(.12)$ & -4.34 \\
\hline TP4 Non-aggressive conduct disorder TR & $.21(.01)$ & $.52(.09)$ & -5.56 \\
\hline TP4 Prosocial behaviour TR & $2.28(.02)$ & $1.94(.10)$ & 3.04 \\
\hline TP4 Anxiety and depression TR & $.89(.02)$ & $1.24(.10)$ & -3.51 \\
\hline TP3 Aggression PR & $.65(.01)$ & $.87(.08)$ & -3.81 \\
\hline TP3 ADHD PR & $1.30(.02)$ & $1.56(.09)$ & -2.86 \\
\hline TP3 Oppositional defiant disorder PR & $.98(.02)$ & $1.39(.10)$ & -4.86 \\
\hline TP3 Non-aggressive conduct disorder PR & $.26(.01)$ & $.43(.05)$ & -3.93 \\
\hline TP3 Prosocial behaviour PR & $2.67(.01)$ & $2.48(.08)$ & 2.75 \\
\hline TP3 Anxiety and depression PR & $.86(.01)$ & $1.06(.08)$ & -3.00 \\
\hline TP4 Aggression PR & $.50(.01)$ & $.77(.05)$ & -5.56 \\
\hline TP4 ADHD PR & $1.26(.02)$ & $1.59(.08)$ & -3.60 \\
\hline TP4 Oppositional defiant disorder PR & $.95(.02)$ & $1.23(.08)$ & -3.35 \\
\hline TP4 Non-aggressive conduct disorder PR & $.26(.01)$ & $.54(.06)$ & -6.39 \\
\hline TP4 Prosocial behaviour PR & $2.73(.01)$ & $2.54(.08)$ & 2.65 \\
\hline TP4 Anxiety and depressions PR & $.89(.01)$ & $1.14(.08)$ & -3.62 \\
\hline TP3 Aggression CR & $.12(.00)$ & $.22(.03)$ & -4.61 \\
\hline TP3 Indirect aggression CR & $.09(.00)$ & $.13(.03)$ & -1.87 \\
\hline TP3 ADHD CR & $.16(.00)$ & $.24(.03)$ & -3.22 \\
\hline TP3 Oppositional defiant disorder CR & $.18(.01)$ & $.27(.04)$ & -2.39 \\
\hline TP3 Non-aggressive conduct disorder CR & $.16(.00)$ & $.23(.03)$ & -2.79 \\
\hline TP3 Prosocial behaviour CR & $.91(.00)$ & $.87(.02)$ & 2.45 \\
\hline TP3 Anxiety and depression CR & $.38(.01)$ & $.44(.03)$ & -1.87 \\
\hline
\end{tabular}


Appendix 1 (cont.).

TP4 Aggression CR

TP4 Indirect aggression CR

TP4 Oppositional towards parents CR

TP4 Aggressive conflict coping CR

TP2 Trustworthiness PeR

TP3 Self-control CR

TP4 Self-control CR

TP4 Expected benefits of delinquency CR

TP4 Risky leisure CR

TP4 Deviance CR

TP4 Police contact CR

TP4 Adult media consumption CR

TP3 Parental involvement PR

TP3 Parental monitoring PR

TP3 Erratic punishment PR

TP4 Involvement PR

TP4 Monitoring PR

TP4 Corporal punishment PR

TP4 Parental involvement CR

TP4 Positive parenting CR

TP4 Parental monitoring CR

TP4 Disclosure to parents CR

TP4 Authoritative parenting CR

TP4 Erratic parenting CR

TP4 Corporal sanctions CR

TP1 Parental conflict PR

TP2 Parental depression PR

TP1 Maternal depression PR

TP3 Parental involvement TR

TP4 Parental involvement TR

TP3 Family climate PR

TP4 School achievement TR

TP3 School motivation TR

TP4 School motivation TR

TP2 Popularity PeR

TP4 Deviant friends CR

TP2 Positive relationships with siblings PR

TP3 Negative peer relations TR

TP4 Negative peer relations TR

TP3 Dominance TR

TP4 Dominance TR

TP4 Peer victimisation CR

TP4 Violent victimisation CR
$.21(.00)$

$.29(.03)$

$-3.25$

$.11(.00)$

$.22(.04)$

$-4.59$

$1.42(.01)$

$1.74(.10)$

$-5.55$

$1.46(.01)$

$1.64(.08)$

$-2.46$

$1.70(.01)$

$2.86(.01)$

$1.95(.01)$

$1.73(.01)$

$1.14(.02)$

$2.54(.06)$

$.03(.00)$

$.89(.03)$

$3.07(.01)$

$3.63(.01)$

$1.18(.02)$

$3.02(.01)$

$3.53(.01)$

$.27(.01)$

$3.34(.01)$

$3.30(.01)$

$3.63(.01)$

$3.43(.01)$

$2.06(.02)$

$1.65(.02)$

$1.21(.01)$

$.05(.00)$

$.78(.01)$

$.05(.00)$

$4.08(.03)$

$4.08(.02)$

3.69 (.01)

$3.30(.03)$

$3.38(.02)$

$3.55(.03)$

$5.00(.08)$

$.05(.00)$

$2.99(.02)$

$1.70(.02)$

$1.78(.02)$

$1.55(.02)$

$1.48(.02)$

$3.16(.08)$

$.44(.02)$
$1.86(.06)$

2.49 (.09)

2.11 (.09)

$-3.20$

5.85

$-2.55$

$-2.89$

$-3.64$

$1.62(.15)$

$-5.36$

$4.20(.39)$

$.09(.04)$

$-2.74$

$1.52(.18)$

$-4.11$

$2.96(.06)$

2.12

$3.53(.06)$

2.05

$1.38(.08)$

$-2.49$

$2.80(.07)$

3.83

$3.37(.06)$

2.87

$.37(.06)$

$-1.65$

$3.08(.08)$

4.11

$3.16(.09)$

1.88

$3.48(.09)$

2.08

$3.00(.12)$

5.55

$2.29(.11)$

$-2.59$

$1.95(.12)$

$-3.37$

1.55 (.10)

$-6.17$

.15 (.03)

$-4.70$

$.86(.06)$

$-1.65$

$.14(.03)$

$-4.56$

$3.44(.16)$

4.40

$3.52(.16)$

4.19

$3.70(.06)$

1.60

$2.94(.14)$

2.20

$3.13(.15)$

2.08

$3.00(.16)$

3.74

$3.93(.43)$

2.37

$.09(.02)$

$-2.84$

$2.76(.09)$

2.66

$2.00(.09)$

$-2.98$

$2.11(.10)$

$-3.18$

$-3.12$

$1.94(.17)$

$-3.25$

$4.88(.53)$

$-3.97$

$.64(.12)$

$-1.96$

Note. $\mathrm{TR}=$ Teacher report, $\mathrm{PR}=$ Parent report, $\mathrm{CR}=$ Child report, $\mathrm{PeR}=$ Peer report, $\mathrm{TP}=$ Time-point. 
Appendix 2. Exploratory factor analysis of covariates.

Factor analysis of covariates.

\begin{tabular}{|c|c|c|}
\hline & $\begin{array}{c}\text { Greatest } \\
\text { |Beta| }\end{array}$ & Factor \\
\hline TP3 Aggression PR & 0.66 & 1 \\
\hline TP3 ADHD PR & 0.57 & 1 \\
\hline TP3 Oppositional defiant disorder PR & 0.57 & 1 \\
\hline TP3 Non-aggressive conduct disorder PR & 0.70 & 1 \\
\hline TP4 Aggression PR & 0.74 & 1 \\
\hline TP4 ADHD PR & 0.52 & 1 \\
\hline TP4 Oppositional defiant disorder PR & 0.57 & 1 \\
\hline TP4 Non-aggressive conduct disorder PR & 0.73 & 1 \\
\hline TP3 Parental monitoring PR & 0.59 & 1 \\
\hline TP4 Monitoring PR & 0.57 & 1 \\
\hline TP3 Aggression TR & 0.79 & 2 \\
\hline TP4 ADHD TR & 0.69 & 2 \\
\hline TP4 Oppositional defiant disorder TR & 0.75 & 2 \\
\hline TP4 Non-aggressive conduct disorder TR & 0.74 & 2 \\
\hline TP4 Prosocial behaviour TR & 0.47 & 2 \\
\hline TP4 Anxiety and depression TR & 0.57 & 2 \\
\hline TP4 Parental involvement TR & 0.50 & 2 \\
\hline TP4 School motivation TR & 0.60 & 2 \\
\hline TP4 Negative peer relations TR & 0.58 & 2 \\
\hline TP4 Dominance TR & 0.61 & 2 \\
\hline TP3 Aggression TR & 0.87 & 3 \\
\hline TP3 Indirect aggression TR & 0.80 & 3 \\
\hline TP3 ADHD TR & 0.64 & 3 \\
\hline TP3 Oppositional defiant disorder TR & 0.72 & 3 \\
\hline TP3 Non-aggressive conduct disorder TR & 0.73 & 3 \\
\hline TP3 Anxiety and depression TR & 0.48 & 3 \\
\hline TP3 Negative peer relations TR & 0.48 & 3 \\
\hline TP3 Dominance TR & 0.76 & 3 \\
\hline TP4 Aggression CR & 0.75 & 4 \\
\hline TP4 Indirect aggression CR & 0.62 & 4 \\
\hline TP4 Aggressive conflict coping CR & 0.74 & 4 \\
\hline TP4 Self-control CR & 0.65 & 4 \\
\hline TP4 Expected benefits of delinquency CR & 0.65 & 4 \\
\hline TP4 Deviance CR & 0.68 & 4 \\
\hline TP4 Disclosure to parents CR & 0.38 & 4 \\
\hline TP4 Deviant friends CR & 0.45 & 4 \\
\hline TP3 Aggression CR & 0.67 & 5 \\
\hline TP3 ADHD CR & 0.75 & 5 \\
\hline TP3 Oppositional defiant disorder CR & 0.66 & 5 \\
\hline TP3 Anxiety and depression CR & 0.66 & 5 \\
\hline TP3 Self-control CR & 0.55 & 5 \\
\hline
\end{tabular}


Appendix 2 (cont.).

\begin{tabular}{|c|c|c|}
\hline TP1 Parental education PR & 0.78 & 6 \\
\hline TP1 Socioeconomic status PR & 0.78 & 6 \\
\hline TP1 Age mother at birth child PR & 0.53 & 6 \\
\hline TP3 Prosocial behaviour PR & 0.66 & 7 \\
\hline TP4 Prosocial behaviour PR & 0.69 & 7 \\
\hline TP3 Parental involvement PR & 0.70 & 7 \\
\hline TP4 Involvement PR & 0.74 & 7 \\
\hline TP3 Parental involvement TR & 0.45 & 8 \\
\hline TP4 School achievement TR & 0.46 & 8 \\
\hline TP3 School motivation TR & 0.64 & 8 \\
\hline TP2 Popularity PeR & 0.41 & 8 \\
\hline Sex & 0.80 & 9 \\
\hline TP3 Prosocial behaviour TR & 0.39 & 9 \\
\hline TP3 Non-aggressive conduct disorder CR & 0.63 & 9 \\
\hline TP4 Oppositional towards parents CR & 0.50 & 10 \\
\hline TP4 Authoritative parenting CR & 0.72 & 10 \\
\hline TP4 Erratic parenting CR & 0.63 & 10 \\
\hline TP4 Corporal sanctions CR & 0.59 & 10 \\
\hline TP3 Anxiety and depression PR & 0.71 & 11 \\
\hline TP4 Anxiety and depressions PR & 0.72 & 11 \\
\hline TP1 Financial problems PR & 0.61 & 12 \\
\hline TP1 Parental criminality PR & 0.59 & 12 \\
\hline TP1 Parental conflict PR & 0.57 & 12 \\
\hline TP1 Maternal depression PR & 0.57 & 12 \\
\hline TP2 Trustworthiness PeR & 0.32 & 13 \\
\hline TP4 Peer victimisation CR & 0.71 & 13 \\
\hline TP4 Violent victimisation CR & 0.71 & 13 \\
\hline TP1 Single parent household PR & 0.62 & 14 \\
\hline TP1 Number of household members PR & 0.78 & 14 \\
\hline TP4 Risky leisure CR & 0.61 & 15 \\
\hline TP4 Adult media consumption CR & 0.49 & 15 \\
\hline TP4 Parental monitoring CR & 0.64 & 15 \\
\hline TP4 Parental involvement CR & 0.66 & 16 \\
\hline TP4 Positive parenting CR & 0.72 & 16 \\
\hline TP3 Indirect aggression CR & 0.56 & 17 \\
\hline TP3 Prosocial behaviour CR & 0.64 & 17 \\
\hline TP3 Erratic punishment PR & 0.53 & 18 \\
\hline TP2 Parental depression PR & 0.66 & 18 \\
\hline TP3 Family climate PR & 0.39 & 19 \\
\hline TP2 Positive relationships with siblings PR & 0.70 & 19 \\
\hline TP4 Police contact CR & 0.64 & 20 \\
\hline TP4 Corporal punishment PR & 0.45 & 21 \\
\hline
\end{tabular}

Note. $\mathrm{TR}=$ Teacher report, $\mathrm{PR}=$ Parent report, $\mathrm{CR}=$ Child report, $\mathrm{PeR}=$ Peer report, $\mathrm{TP}=$ Time-point. Estimates obtained using varimax rotation. 


\section{Appendix 3. Balance statistics before and after GBM.}

Standardised bias and t-tests.

\begin{tabular}{|c|c|c|c|c|c|c|c|c|}
\hline \multirow[b]{2}{*}{ Factor } & \multicolumn{4}{|c|}{ Before matching } & \multicolumn{4}{|c|}{ After matching } \\
\hline & $\begin{array}{l}\text { Mean } \\
\text { out-of- } \\
\text { home } \\
\text { care } \\
\text { group }\end{array}$ & $\begin{array}{c}\text { Mean } \\
\text { non-out- } \\
\text { of-home } \\
\text { care } \\
\text { group }\end{array}$ & $\begin{array}{c}\text { Standar- } \\
\text { dised } \\
\text { bias }\end{array}$ & $\begin{array}{c}\text { \% signifi- } \\
\text { cant t- } \\
\text { tests }\end{array}$ & $\begin{array}{l}\text { Mean } \\
\text { out-of- } \\
\text { home } \\
\text { care } \\
\text { group }\end{array}$ & $\begin{array}{c}\text { Mean } \\
\text { non-out- } \\
\text { of-home } \\
\text { care } \\
\text { group }\end{array}$ & $\begin{array}{c}\text { Standar- } \\
\text { dised } \\
\text { bias }\end{array}$ & $\begin{array}{c}\text { \% signifi- } \\
\text { cant t- } \\
\text { tests }\end{array}$ \\
\hline Factor 1 & 0.37 & -0.01 & 0.56 & $100 \%$ & 0.00 & -0.01 & 0.02 & $0 \%$ \\
\hline Factor 2 & 0.52 & -0.02 & 0.82 & $100 \%$ & 0.08 & -0.01 & 0.15 & $10 \%$ \\
\hline Factor 3 & 0.38 & -0.01 & 0.55 & $100 \%$ & 0.14 & -0.01 & 0.20 & $0 \%$ \\
\hline Factor 4 & 0.38 & -0.01 & 0.58 & $90 \%$ & 0.02 & -0.01 & 0.04 & $0 \%$ \\
\hline Factor 5 & 0.38 & -0.01 & 0.56 & $100 \%$ & 0.13 & -0.01 & 0.19 & $0 \%$ \\
\hline Factor 6 & -0.37 & 0.01 & -0.48 & $100 \%$ & -0.08 & 0.01 & -0.11 & $0 \%$ \\
\hline Factor 7 & -0.28 & 0.01 & -0.38 & $80 \%$ & -0.09 & 0.01 & -0.12 & $0 \%$ \\
\hline Factor 8 & -0.38 & 0.01 & -0.60 & $100 \%$ & -0.07 & 0.01 & -0.12 & $20 \%$ \\
\hline Factor 9 & -0.18 & 0.01 & -0.24 & $20 \%$ & 0.15 & 0.00 & 0.19 & $10 \%$ \\
\hline Factor 10 & 0.47 & -0.02 & 0.70 & $100 \%$ & -0.03 & -0.01 & -0.02 & $0 \%$ \\
\hline Factor 11 & 0.40 & -0.02 & 0.47 & $90 \%$ & 0.13 & -0.01 & 0.17 & $20 \%$ \\
\hline Factor 12 & 0.82 & -0.03 & 1.30 & $100 \%$ & 0.13 & -0.02 & 0.24 & $30 \%$ \\
\hline Factor 13 & 0.37 & -0.01 & 0.55 & $90 \%$ & -0.04 & -0.01 & -0.05 & $0 \%$ \\
\hline Factor 14 & 0.49 & -0.02 & 0.61 & $100 \%$ & 0.07 & -0.01 & 0.10 & $0 \%$ \\
\hline Factor 15 & 0.27 & -0.01 & 0.38 & $60 \%$ & -0.11 & -0.01 & -0.15 & $10 \%$ \\
\hline Factor 16 & -0.41 & 0.02 & -0.52 & $90 \%$ & -0.02 & 0.01 & -0.04 & $0 \%$ \\
\hline Factor 17 & 0.19 & -0.01 & 0.25 & $40 \%$ & 0.06 & 0.00 & 0.07 & $0 \%$ \\
\hline Factor 18 & 0.25 & -0.01 & 0.34 & $50 \%$ & -0.10 & -0.01 & -0.12 & $0 \%$ \\
\hline Factor 19 & -0.15 & 0.01 & -0.19 & $20 \%$ & 0.00 & 0.00 & 0.00 & $10 \%$ \\
\hline Factor 20 & 0.24 & -0.01 & 0.24 & $10 \%$ & 0.18 & -0.01 & 0.15 & $0 \%$ \\
\hline Factor 21 & 0.26 & -0.01 & 0.27 & $50 \%$ & -0.05 & -0.01 & -0.04 & $10 \%$ \\
\hline
\end{tabular}

Note. Numbers pooled across imputations. Estimates obtained using Generalised Boosted Models with n.trees $=10000$, interaction.depth $=4$, and shrinkage $=0.0005$. 